\title{
MERDEKA BELAJAR DALAM PERSPEKTIF PENDIDIKAN ISLAM DAN IMPLEMENTASINYA DI SMK ISLAM INSAN MULIA
}

\author{
Nurlaeli*, Fitriana**, Bunyanul*** \\ *lelymumtaz25@gmail.com,**fitrifirda99@gmail.com,***abunyanul@gmail.com \\ *Magister PAI Program Pascasarjana, Universitas Muhammadiyah Tangerang
}

\begin{abstract}
The Freedom of learning Policy issued by the Minister of Education and Culture (Mendikbud) Nadiem Makarim on November 22, 2019 changed many things in the national education process. Starting from learning practices that place more emphasis on student interests, the assessment process that no longer focuses on cognitive abilities and is handed over to the head of the education unit, to the process of preparing the Lesson Plan (RPP) which is simpler.In the world of Islamic education, this concept is not new. Since classical times, education in Islam has emphasized independence. However, the concept is not institutionalized. Therefore, when the Minister of Education and Culture Nadiem Makarim issued this policy, it seemed as if it was a new thing.Insan Mulia Islamic Vocational School is preparing to apply the concept of Independent Learning. However, its implementation is not optimal. There are two obstacles. First, because this policy is still new, schools still need examples or comparative studies with other schools that have implemented this policy first. Second, the Covid-19 pandemic, which has lasted for almost 2 years, has made the teaching and learning process more carried out online.
\end{abstract}

Keywords: Freedom of Learning, Islamic Education, Nadiem Makarim

\section{PENDAHULUAN}

Perkembangan zaman mengubah cara hidup, bekerja, menghadapi masalah, juga berkomunikasi secara lokal, nasional, maupun internasional. (Hermino, 2020:1). Perubahan ini jadi tantangan yang harus dihadapi dan dirumuskan dengan baik solusinya. Salah satu yang harus menjadi tameng adalah pendidikan. Aspek keterampilan dan sosial emosional yang mendukung pada era ini tidak boleh diabaikan di dunia pendidikan. Guru dan siswa dituntut lebih melek teknologi dan kecakapan keterampilan. Hal ini sesuai dengan kompetensi yang dibutuhkan untuk menghadapi globalisasi dan Revolusi Industri 4.0.

Menguasai kompetensi ini amat penting. Menurut Muhammad Nurizal, dosen Universitas Gadjah Mada (UGM)/ pendiri Gerakan Sekolah Menyenangkan
(GSM), kompetensi pengetahuan yang dibutuhkan di era Revolusi Industri hanya $10 \%$. Yang terbesar adalah kompetensi memecahkan persoalan nyata yang kompleks (36\%), kompetensi social skill seperti kemampuan berkomunikasi, berkolaborasi, bekerja sama, dan lainnya (16\%), kemampuan berpikir logic atau critical thinking atau berpikir kritis (17\%), dan me-monitoring diri sendiri dan membuat keputusan-keputusan sendiri secara efisien dan efektif (17\%).

Pendidikan selama ini kurang berhasil menciptakan kompetensi itu. Penyebabnya, tak ada kebebasan dalam belajar. Peserta hanya didik dituntut menghafal semua materi pembelajaran dan dibatasi dengan berbagai peraturan belajar, sehingga semangat kritis dan kreatif mereka terpasung. Sementara, pendidik dibebani tumpukan tugas-tugas 
administrasi yang melalaikan tugas utamanya, yaitu mendidik. Padahal, esensi jati diri adalah pengembangan kreativitas dan ekspresi pribadi manusia (Herly Janet Lesilolo, 2015:11-15).

Kemudian, keluarlah kebijakan Merdeka Belajar. Ada empat pokok kebijakan dalam Merdeka Belajar, yakni mereformasi sektor Ujian Sekolah Berstandar Nasional (USBN), Ujian Nasional (UN), Rencana Pelaksanaan Pembelajaran (RPP), dan Peraturan Penerimaan Peserta Didik Baru (PPDB) Zonasi. USBN digantikan dengan ujian asesmen. UN dihentikan dan digantikan dengan asesmen kompetensi minimum, RPP dipersingkat menjadi satu halaman, dan zona PPDB dibuat lebih fleksibel.

Dengan kebijakan ini, sekolah bisa lebih mengembangkan kurikulum yang sesuai dengan visi misi sekolah. Karena sudah tidak terikat lagi dengan tujuan akhir UN dan USBN. Guru pun lebih merdeka dalam menentukan pilihan materi yang akan diberikan kepada peserta didik. Tentu pemilihan materi ini harus melalui observasi dahulu untuk menentukan yang benar-benar sesuai dengan kondisi dan situasi serta yang dapat menunjang potensi dan kebutuhan peserta didik.

Dengan adanya Merdeka Belajar, keterlibatan siswa dalam pembelajaran akan meningkat. Mereka akan lebih bahagia saat belajar. Siswa yang bahagia cenderung lebih giat belajar sehingga kontribusi mereka meningkat dengan signifikan ketimbang mereka yang tidak sedang bahagia (Delpianus Piong, 2020: 291).

Dalam Islam, konsep kemerdekaan sangat dijunjung tinggi. Allah memberi kebebasan manusia melaksanakan aktivitas apa pun yang diinginkannya. Namun, setiap pilihan dari kebebasan itu terdapat konsekuensinya. Yang baik akan mendapat kebaikan, dan yang jelek akan mendapat keburukan. Kebebasan ini pun ada di dunia Pendidikan Islam.

Merdeka Belajar sebenarnya bukan hal baru di dunia Pendidikan Islam. Di pesantren misalnya, dalam hal evaluasi, sudah lumrah dengan membuat sistem evaluasi tersendiri yang berbeda dengan sistem yang ditentukan Pemerintah. Biasanya dinamakan imtihan. Materi yang diujikan sesuai dengan yang diberikan ke santri dan kompetensi yang ditentukan pesantren.

\section{HASIL DAN PEMBAHASAN}

\section{Teori Merdeka Belajar}

Dalam Kamus Besar Bahasa Indonesia (KBBI) Daring Kementerian Pendidikan dan Kebudayaan, "merdeka" diartikan bebas, berdiri sendiri, tidak terkena atau lepas dari tuntutan, tidak terikat, tidak bergantung kepada orang. Sedangkan "belajar" berarti berusaha memperoleh kepandaian atau ilmu, berlatih, berubah tingkah laku atau tanggapan yang disebabkan oleh pengalaman. Apabila ditarik dari arti kedua kata tersebut, "merdeka" dan "belajar"; Merdeka Belajar adalah belajar yang leluasa, bebas tidak terikat, yang menggerakan peserta didik agar mengembangkan seluruh potensi mereka agar mencapai kapabilitas intelektual, moral, dan keterampilan lainya.

Ada tiga aspek dalam belajar. Yaitu (1) adanya perubahan perilaku akibat adanya pendidikan dan latihan serta pengalaman, (2) adanya pendidikan dan latihan, (3) adanya pengalaman (Seto Mulyadi, 2017:34). Gagne menyatakan, belajar merupakan aktivitas mental intelektual yang bersifat internal (Jamaludin, 2015:9). Aktivitas belajar aktualisasinya adalah proses beroperasinya mental-intelektual anak.

Mc Geoch (Bulgeski, 1956: 459-469) mendefinisikan belajar sebagai "a change in performance as a result of practice". Belajar merupakan perubahan penampilan sebagai akibat latihan. Menurut Piaget, belajar adalah sebuah proses interaksi anak didik dengan lingkungan yang selalu mengalami perubahan dan dilakukan secara terus menerus (Abuddin Nata, 2009:99). 
Merdeka Belajar diinisiasi Nadiem Makarim menjadi suatu kebijakan pertama kali disampaikan pada Hari Guru, 25 November 2019. Tiga hari sebelumnya, yaitu 22 November 2019, naskah itu diunggah di situsweb resmi Kemendikbud dan viral di media sosial.

Dengan Merdeka Belajar ini diharapkan dapat menciptakan suasana belajar yang bahagia, baik bagi murid maupun para guru. Guru menciptakan proses pembelajaran yang bisa membuat siswa lebih kreatif untuk menimba ilmu secara mendalam dan menciptakan suasana belajar yang membahagiakan.

Berikut ini konsep yang dapat dipraktikkan dalam Merdeka Belajar:

- Komitmen pada Tujuan

Komitmen seseorang pada merdeka belajar adalah ketekunannya dalam menuju tujuan yang bermakna bagi dirinya. Menetapkan tujuan yang jelas dalam belajar merupakan aspek yang penting.

- Kemandirian Belajar

Dalam pendidikan, kemandirian disebut Self Regulated Learning (SRL). Menurut Suhendri (2012), kemandirian merupakan sikap mental positif dari seorang individu untuk kenyamanan melakukan kegiatan perencanaan untuk mencapai tujuan dengan memposisikan atau mengkondisikan dirinya sehingga dapat mengevaluasi tentang diri sendiri dan lingkungannya. Kemandirian sangat penting bagi siswa. Siswa mandiri lebih cepat menerima materi pembelajaran sehingga membentuk karakter siswa menjadi lebih baik (Diniyah, 2018:15).

- Menumbuhkan Social Emotional Learning (SEL)

Casel mendefiniskan SEL sebagai proses yang dilalui anak-anak dalam menentukan dan mengaplikasikan pengetahuan, dan keterampilan secara efektif untuk memahami/mengatur emosi, mengatur tujuan positif, dan merasa atau menunjukkan empati pada orang lain (Haleludin, 2019:6).

\section{Praktik Merdeka Belajar}

Secara konsep dan praktis, Merdeka Belajar telah digalakkan berbagai komunitas guru dan sekolah, seperti Gerakan Guru Belajar dan Gerakan Sekolah Menyenangkan. Di Gerakan Guru Belajar yang diinisiasi Najeela Shihab, merk Merdeka Belajar bahkan telah didaftarkan Sekolah Cikal sejak 2015 (CNN Indonesia, 2020).

Semangat Merdeka Belajar Sekolah Cikal dan dari gerakan lainnya searah dengan kebijakan Merdeka Belajar dari Kemendikbud. Suatu gerakan di akar rumput yang dianggap baik kemudian diangkat menjadi kebijakan tentu hasilnya akan lebih baik, ketimbang jika berseberangan dengan kebijakan pemerintah.

\section{Landasan Merdeka Belajar}

Payung hukum Merdeka Belajar adalah UU Nomor 20 Tahun 2003 tentang Sistem Pendidikan Nasional dan Surat Edaran (SE) Mendikbud Nomor 1 Tahun 2020 tentang Kebijakan Merdeka Belajar dalam Penentuan Kelulusan Peserta Didik dan Penerimaan Peserta Didik Baru Tahun Ajaran 2020/2021.

Selain itu, Merdeka Belajar juga memiliki landasan folosfis. Dari hasil analisi penulis, empat aliran filsafat pendidikan yang melandasi kebijakan ini.

- Progresivisme

Progresivisme menekankan bahwa pendidikan harus berpusat pada anak, bukan memfokuskan pada guru atau atau bidang muatan (Uyoh Sadulloh, 2010:143). Aliran filsafat pendidikan progresivisme dimotori gagasan John Dewey. Mohamad Ali (2017:53-54) merangkum ada tiga konsep kunci pemikiran pendidikan John Dewey, yaitu: intelegence (kecerdasan), experience (pengalaman), dan progress (berkemajuan).

Kecerdasan (intelligence) adalah alat utama manusia untuk memahami dan memecahkan masalah. Pengalaman (experience) sebagai interaksi manusia dengan lingkungannya. Sedangkan konsep kemajuan (progress) berkaitan dengan 
lingkungan yang ingin diubah manusia dengan kecerdasannya.

Progresivisme memandang proses belajar pada pembentukan kreativitas, pemberian kegiatan yang berpusat pada siswa, suasana yang alamiah dengan memperhatikan pengalaman peserta didik, sehingga diharapkan dapat tercipta perubahan pada diri peserta didik dengan indikator adanya perkembangan tingkat kemajuan baik dalam bentuk pemikiran maupun sikap.

\section{- Konstruktivisme}

Aliran filsafat ini melihat pengalaman langsung peserta didik (direct experiences) sebagai kunci dalam pembelajaran. Menurut aliran ini, pengetahuan adalah hasil konstruksi atau bentukan manusia. Aliran ini memiliki kesamaan dengan empirisme yang mengatakan bahwa sumber pengetahuan adalah pengalaman (apposteriory) panca indera (Muslikh, 2020:41)

- Humanisme Carl R. Roger.

Filsafat pendidikan humanisme memandang belajar bukan sekadar pengembangan kualitas kognitif, tetapi juga emosi atau perasaan, komunikasi yang terbuka, dan nilai-nilai yang dimiliki setiap siswa. Pendidikan dengan mengedepankan filsafat humanisme memandang proses belajar juga bagian dari mengembangkan nilai-nilai kemanusiaan (Baharuddin dan Esa Nur Wahyuni, 2007:142-143).

Carl R. Roger memandang manusia adalah makhluk otonom yang senantiasa berusaha untuk mengembangkan seluruh kemampuan dirinya demi kelangsungan hidupnya. Pengolahan diri, konstruksi individual dan cara mengelola diri secara merdeka adalah unsur utama dan penting yang menentukan pencapaian aktualisasi dirinya (Holosko et al., 2008).

- Pembebasan Paulo Freire

Menurut Paulo Freire, dalam pendidikan kebebasan ada dua model, yaitu model pendidikan humanisasi dan model pendidikan koseintisasi. Model pendidikan humanisasi adalah suatu proyeksi pendidikan yang berakar dari kegelisahan Freire mengenai sejumlah praktik pendidikan tidak manusiawi (dehumanisasi). Selanjutnya, model pendidikan pembebasan kosientisasi atau kesadaran kritis. Menurut Freire, kesadaran adalah melakukan kritik. Melakukan pencarian makna baru, makna yang lebih baik. Karena itu, sifat dari kesadaran adalah transformative.

\section{Perspektif Pendidikan Islam}

Dalam Bahasa Arab, pendidikan disandingkan dengan tiga istilah, yakni tarbiyah, ta' lim dan ta'dib. Ketiganya mempunyai kesamaan, baik secara tekstual maupun kontekstual. Dalam term tarbiyah, pendidikan dapat diartikan sebagai perbuatan secara sengaja dan sadar, terencana, bersifat gradual atau bertahap agar meneladani sifar-sifat Rabbaniah. Ta'lim diartikan sebagai pengajaran atau pemberian informasi atau transmisi pengetahuan. Sedangkan $t a^{\prime} d i b$ diartikan sebagai pembimbingan dan pengenalan yang berangsur-angsur akan penciptanya.

Pendidikan Islam memiliki karakteristik berbeda dari pendidikan umum. Beberapa pakar pendidikan Islam seperti Yusuf Qardhawi menyatakan, pendidikan Islam merupakan pendidikan manusia seutuhnya, akal dan hatinya, ruhani dan jasmaninya, akhlak dan keterampilannya. Pendidikan Islam menyiapkan manusia untuk hidup, baik dalam keadaan aman maupun perang, dan menyiapkan untuk menghadapi masyarakat dengan segala kebaikan dan kejahatannya, manis dan pahitnya (Yusuf Qardawi, 1980:39).

Haedar Nashir dalam Mohamad Ali (2017:17) mengatakan, pendidikan Islam adalah ikhtiar menjadikan manusia mampu menjalankan peran sebagai khilafah di muka bumi (khalifah fil ardl). Menjadi khalifah berarti manusia, baik individu maupun kolektif, berfungsi sebagai pelaku sejarah perubahan untuk memakmurkan dan membangun peradaban hidup yang utama, yang membedakan hidup manusia dari hidup makhluk Tuhan lainnya. 
Jika dikaitkan dengan pendidikan Islam, Merdeka Belajar identik dengan pendidikan pembebasan. Islam sangat menekankan pendidikan pembebasan. Konsep dasar kebebasan dalam Islam dapat kita temukan dari kebebasan dasar manusia, termasuk dalam memilih agama. Dalam Q.S. Al-Kafirun ayat 6 Allah berfirman:

Artinya: "Untukmu agamamu, dan untukukulah agamaku."

\section{Hakikat Merdeka Perspektif Pendidikan Islam}

Istilah kemerdekaan dalam Bahasa Arab disebut "al-Istiqlāl". Artinya, bebas dan lepas dari segala bentuk ikatan dan penguasaan pihak lain. Kata lain untuk makna ini adalah "Al-Hurriyyah", yang biasa diterjemahkan kebebasan. Dari kata ini, terbentuk kata "al-Tahrir" yang berarti pembebasan. Orang yang bebas/merdeka disebut "al-hurr", lawan dari "al'abd" (budak). Kata "al-hurriyah" inilah yang sering ditafsirkan dalam Al-Qur'an bukan kata "Istiqlal".

Namun, tentu saja kemerdekaan dalam Islam bukan berarti tanpa batasan. Direktur Pondok Pesantren at-Taqwam Depok, Jawa Barat, Dr Muhammad Adriansyah mengatakan, kebebabasan dalam Islam bukan semaunya. Konsep kebebasan dalam Islam dikenal dengan istilah ikhtiar. Istilah itu satu akar dengan khair, yang artinya baik. Jadi, manusia diberikan kebebasan untuk memilih tapi harus mengandung kebaikan di dalamnya. Kalau kebebasan tidak disertai dengan kebaikan, itu salah, itu kemerdekaan yang tidak benar.

Kemerdekaan adalah salah satu hak dasar bagi manusia. Menurut Hamka, kemerdekaan adalah semangat hidup manusia dan tonggak kejayaannya (Hamka, 1990:161). Manusia dilahirkan merdeka. Ia lahir ke dunia dengan tidak mengenal perbedaan. Karena itu, di kehidupannya, manusia hendaknya tetap menjadi orang.

Kemerdekaan yang melekat pada manusia itu terbatas. Bebas merdeka bukan berarti semua merdeka untuk dilakukan. Kebebasan dalam Islam dibatasi hukum dan syariat. Batasan tersebut bisa ditemukan dalam Al-Qur'an dan hadits.

Buya Hamka, pada ceramahnya yang terkumpul dalam buku "Doktrin Islam yang Menimbulkan Kemerdekaan dan Keberanian" mengungkapkan, hakikat kemerdekaan sebenarnya tidak lain "memperhambakan diri atau mengakui diri jadi budak kebenaran." Tidak ada yang boleh memperbudak seorang Muslim, selain Allah (Muhammad Hafil, 2021).

Ada tiga pokok hakikat kemerdekaan itu menurut Hamka, yaitu merdeka iradah (kemauan), merdeka pikiran atau bebas menyatakan pikiran, dan merdeka jiwa yaitu bebas dari ketakutan. Hakikat kemerdekaan ini dapat dijadikan landasan dalam mengaplikasikan proses Merdeka Belajar.

\section{Siswa Merdeka dan Guru Merdeka}

Menurut Buya Syafi'i Ma'arif, pendidikan harus diubah secara radikal agar memiliki visi ke depan dan mampu memberikan pencerahan. Selama ini, sistem pendidikan dianggap masih belum memberikan ruang kreativitas dan keingintahuan pelajar. Oleh sebab itu, menurut Buya Syafi'i Ma'arif, sistem dan orientasi pendidikan yang diusulkan adalah model pendidikan yang dapat membebaskan (baca: memerdekakan) manusia dari budaya yang serba verbal, mekanistik dan dangkal (Ahmad Syafi'i Ma'arif, 1993:148).

Untuk membentuk siswa menjadi manusia seutuhnya yang memiliki kemerdekaan, kita dapat melihat kriteria peserta didik yang diungkapkan Samsul Nizar (2005, 48-50): (1) Peserta didik bukan miniatur orang dewasa tetapi memiliki dunianya sendiri; (2) Peserta didik punya periodesasi perkembangan dan pertumbuhan; (3) Peserta didik adalah makhluk Allah yang memiliki perbedaan individu baik disebabkan oleh faktor bawaaan maupun lingkungan ia berada; (4) Peserta didik merupakan dua unsur utama, jasmani dan rohani, unsur jasmani 
memiliki daya fisik dan unsur rohani memiliki daya akal hati nurani dan nafsu; (5) Peserta didik adalah manusia yang memiliki potensi atau fitrah yang dapat dikembangkan dan berkembang secara dinamis.

Memposisikan siswa yang merdeka adalah menjadikannya sebagai subjek dalam proses belajar. Memberikan mereka ruang untuk yang membuat keputusan sendiri dalam menjalani proses pembelajarannya. Membuat keputusan sendiri adalah salah satu unsur dalam proses Merdeka Belajar.

Perjalanan Buya Hamka selama mencari ilmu dapat dijadikan contoh murid merdeka, membuat keputusan sendiri dalam menjalani proses belajarnya. Dalam webinar Paradigma Pendidikan Merdeka Belajar Ala Buya Hamka, Prof dr. Fasli Jalal mengatakan, di masa Buya Hamka sekolah hanya mengajarkan hapalan, tidak memberikan kesempatan siswa berekploasi. Buya Hamka tidak nyaman dan akhirnya memilih berguru ke Engku Zaenudin Labay. Engku Zaenudin Labay inilah yang ikut memerdekan dan membuka cakrawala intelektual Buya Hamka tentang dunia luar.

Petikan kisah Buya Hamka itu sinkron dengan pernyataan Nadiem Makariem bahwa peserta didik akan menjadi merdeka jika gurunya dapat memerdekakannya dan memerdekakan dirinya sendiri. Nadiem menegaskan, Merdeka Belajar yang tidak terjadi di guru tidak mungkin terjadi di murid. Sebelum guru memahami peserta didik sebagai manusia yang merdeka, dia juga harus memahami dirinya sebagai guru merdeka.

Dalam pendidikan Islam, Nabi Muhammad SAW kerap dijadikan contoh bagaimana menjadi guru yang ideal. Beliau bukan hanya mudarris, tetapi juga muallim, muzakki, murabbi, mu'addib, murshid dan mutli. Maka, sangat besar tanggung jawab seorang pendidik, karena pendidik bukan hanya berkewajiban mentransfer ilmu, tetapi juga harus memelihara dan melestarikan aspek jasmani dan ruhani peserta didik.
Sosok guru ideal dan merdeka dalam perspektif pendidikan Islam diharapkan mempunyai kriteria sebagai berikut; (1) Guru berperan sebagai teladan (uswah), figur yang ideal di mata peserta didiknya; (2) pengarah, penasihat, dan pemberi petunjuk dan memonitor; (3) mediator dan fasilitator; (4) mitra peserta didik; (5) menjadikan hasil refleksi dan evaluasi sebagai pangkal perubahan; (6) punya prinsip merdeka berpikir; (7) memiliki sikap terbuka.

\section{Merdeka Berpikir Perspektif Pendidikan Islam}

Esensi Merdeka Belajar adalah merdeka dalam berpikir, baik secara individu maupun secara berkelompok, sehingga bisa melahirkan peserta didik yang kritis, kreatif, kolaboratif, inovatif, dan partisipatif. Menurut Hamka, ada dua prinsip dasar yang dapat menunjang dan menjadikan kemajuan dan kejayaan manusia, yaitu: prinsip keberanian dan prinsip kemerdekaan berpikir (Shafiah dan M. Mukhlis, 2010:58). Kedua prinsip ini menimbulkan berbagai macam pengetahuan. Tanpa keduanya, ilmu pengetahuan tidak pernah muncul serta kejayaan hanya berada dalam angan-angan.

Allah SWT menganugerahkan akal kepada manusia secara khusus, karena tidak dimiliki makhluk lain. Dengan akal, manusia bisa melihat potensi-potensi yang terdapat di alam dan di lingkungan sekitar. Islam sangat menghargai orang yang berpikir. Untuk sebutan orang Muslim yang berpikir, Al-Qur'an menggunakan istilah "ulul albab" (orang yang berpikir), "ulul ilmi" (orang yang berilmu), "ulul abshar" orang yang mempunyai pandangan, dan "ulu al-nuha" orang yang bijaksana (Hasyim Syah Nasution, 1999:47).

Orang yang berakal pada dasarnya adalah orang merdeka, merdeka dari segala hal yang membuatnya merasa takut dan terikat kepada selain Allah. Buya Hamka mengatakan, orang yang berakal adalah orang yang tidak memiliki tempat takut, 
kecuali kepada Tuhannya (Adian Husaini, 2020).

Dalam Islam, kemerdekaan berpikir sangat dihargai. Hal ini dapat dilihat dari perjalanan historis Islam awal pada zaman Nabi dan sahabatnya. Menurut Syekh Syaukat Hussain (1996: 71-73), terdapat bukti-bukti yang menunjukkan bahwa Nabi memberikan kemerdekaan ke para sahabat untuk berbicara dan mengemukakan pendapat. Hal ini tampak dalam musyawarah-musyawarah atau konsultasi beliau untuk membahas berbagai persoalan atau pemberian kelonggaran untuk menentukan pilihan. Merdeka Belajar dalam Perspektif Islam

Guru Besar Pendidikan Islam yang juga Rektor Universitas Islam Negeri (UIN) Sunan Gunung Djati Bandung, Prof Mahmud, mengatakan, Merdeka Belajar sejalan dengan pendidikan Islam. Dia menyebutkan, dalam hadits disebutkan, belajar adalah fardu. Selama untuk kepentingan ilmu, di mana saja maka harus diambil. "Bahkan, dalam qaul ulama disebutkan, uthlubul ilma walua bishin, tuntutlah ilmu walau sampai ke negeri China. Artinya, menggambarkan bahwa belajar itu boleh di mana saja. Maka, Merdeka Belajar sinkron dengan konsep belajar dalam Islam," terangnya, dalam wawancara dengan penulis.

Sejak awal, Islam sudah memerdekan proses pencarian ilmu. Belajar bisa dilakukan di mana saja, tidak hanya di satu tempat. Merdeka dalam belajar adalah merdeka memilih. Peserta didik merdeka memilih materi yang hendak dia pelajari dengan guru yang sesuai dengan pilihannya. Peserta didik juga merdeka memilih tempat dia untuk belajar.

Dr. Adriansyah menjelaskan, dalam pandangan Islam, murid diberikan kesempatan membaca, mencari sumbersumber belajar lain, belajar di banyak tempat. Tapi, mereka tidak dilepas total. Sebab, hal itu bisa membuat murid tersebut liar. Peran guru tetap penting. Guru tetap perlu mengarahkan murid tersebut.
Dalam merdeka belajar perfektif pendidikan Islam, sosok guru tetap memeliki peran penting. Guru yang memberikan kebebasan kepada peserta didik, tapi tetap memberikan bimbingan dan tuntunan.

"Kalaupun diberi kebebasan baca buku, guru tetap harus memberikan acuan buku-buku yang benar. Jangan sampai murid tidak punya dasar, akhirnya memilih buku-buku salah".

Berkaitan kemerdekaan memilih materi pembelajaran, menurut Adriansyah, dalam Islam dikenal konsep pembagian ilmu. Ada yang masuk dalam kategori ilmu fardu 'ain, ada yang masuk dalam kategori fardu kifayah.

"Yang fardu 'ain itu adalah ilmu yang mesti dipelajari setiap Muslim. Sedangkan yang fardu kifayah itu adalah pelajaran-pelajaran yang menjadi pilihan. Tidak wajib untuk semua Muslim, tapi disesuaikan dengan kebutuhan umat. Misalnya, umat butuh dokter karena sekarang banyak yang wafat, maka harus ada sebagian murid yang mendalami ilmu kedokteran."

Dengan pemahaman bahwa peserta didik adalah manusia yang merdeka dengan segala potensinya inilah, diharapkan peserta didik mempunyai sifat kemanusiaan yang memerdekan tidak hanya untuk dirinya tapi juga untuk lingkungannya, umat pada umumnya. Dalam Islam sikap dan sifat ini sangat diutamakan. Islam adalah agama yang datang untuk memerdekakan yang tertindas dengan saling tolong menolong.

\section{Kebijakan Merdeka Belajar Perspektif}

- UN dan USBN

Ada empat pokok kebijakan Merdeka Belajar, yaitu yang berhubungan dengan Ujian Sekolah Berstandar Nasional (USBN), Ujian Nasional (UN), Rencana Pelaksanaan Pembelajaran (RPP), dan Peraturan Penerimaan Peserta Didik Baru (PPDB) Zonasi. Dari empat tersebut, dua berkaitan dengan proses evaluasi, yakni UN dan USBN. UN kini telah dihapus. 
Kini, proses evaluasi sepenuhnya dikembalikan ke sekolah.

Evaluasi dalam Merdeka Belajar tidak lagi disamaratakan, melainkan dilakukan sesuai ketercapaian dan kemampuan peserta didik dalam penyerapan materinya. Kebijakan tersebut selaras dengan Pendidikan Islam. Sebagaimana terkandung dalam Surat AlZalzalah serta ayat-ayat lain dalam AlQur'an yang menunjukkan adanya kebebasan dalam hal bertindak di dunia, walaupun terdapat balasan sesuai dengan pilihan yang dilaksanakan di dunia (Ano Suharna, 2016: 49-68).

Ayat ini mengajarkan kita tentang kebebasan atau kemerdekaan dalam bertindak dan bertanggung jawab atas semua perbuatan dan pilihan yang kita buat. Sebab, sekecil apa pun perbuatan tersebut, akan mendapat balasan. Dalam analogi pembelajaran, menurut Eva Dwi, siswa dibebaskan dalam mendapat informasi dan pembelajaran. Sebab, semua akan dinilai secara komprehensif oleh sekolah, bukan oleh Pemerintah (Eva Dwi Kumala Sari, 2017:17-28).

Dalam Pendidikan Islam, evaluasi dapat ditemukan dalam beberapa istilah. Seperti al-hisab, al-imtihan, dan al-ihktibar (Suharna, 2016:59-61). Beberapa hadits juga menerangkan mengenai evaluasi. Rasulullah sering mengevaluasi hafalan para sahabat dengan menyuruh membaca ayat-ayat Al-Qur'an di hadapannya. Rasulullah membetulkan hafalan dan bacaan mereka yang keliru. Nabi juga mengevaluasi kemampuan sahabat untuk dijadikan utusan ke suatu daerah mengajarkan agama Islam.

- RPP Satu Halaman

Nadiem Makarim menuturkan, RPP cukup dibuat satu halaman. Melalui penyederhanaan ini, diharapkan waktu guru dapat dioptimal ke kegiatan belajar. Komponen RPP hanya perlu tiga inti, yaitu tujuan pembelajaran, langkah-langkah pembelajaran (kegiatan), dan penilaian pembelajaran (asesmen). Dengan adanya kebijakan ini, tujuan pendidikan Agama
Islam akan tercapai, karena banyaknya waktu guru melakukan pendekatan, pembinaan, transfer of knowledge, hingga penilaian.

RPP satu halaman memberikan fleksibilitas bagi guru untuk merancang rencana proses pembelajarannya. Guru memiliki wewenang dan keleluasaan penuh tanpa adanya intervensi dari satuan pendidikan sebagai lembaga penyelenggara. Guru Pendidikan Agama Islam lebih leluasa lagi memilih materi dan metode pembelajaran yang sesuai dengan kebutuhan peserta didiknya.

- Merdeka Belajar, Telaah Pendidikan Pesantren dan Sejarah Pendidikan Islam

Dalam konteks kurikulum, Merdeka Belajar telah lama diterapkan sekolah Islam atau pesantren. Di sekolah Islam misalnya, penentuan materi tambahan, jam belajar tambahan, kompetensi tambahan, dan lain sebagainya biasanya berbeda dengan sekolah negeri. Sekolah swasta dan pesantren mempunyai kurikulum tersendiri dan tujuan kompetensi yang berbeda dan mempunyai ciri khas sendiri, tapi tentu saja masih dalam lingkup kurikulum nasional.

Prof. Mahmud mengatakan, "Tradisi pembelajaran di pesantren sangat erat dengan kemerdekaan belajar, seperti sorogan (belajar lintas pesantren). Dilihat dari tradisinya, Merdeka Belajar dalam khazanah pendidikan Islam itu sudah dilakukan oleh para pesantren, oleh ulama".

Dalam evaluasi, di pesantren sudah lumrah membuat sistem tersendiri. Biasanya dinamakan imtihan. Imtihan ini ada yang lisan ada yang tertulis. Materi yang menjadi acuan imtihan sesuai dengan yang telah diberikan kepada santri dan kompetensi yang telah ditentukan pesantren. Bentuk pertanyaan dalam evaluasi di pesantren tidak dalam bentuk pertanyaan multiple choice, tapi berbentuk esai.

"Soal seperti itu membuka analisis santri. Mereka menjawab dengan pendapat 
sendiri yang merangsang untuk bisa menulis dan berpikir kritis. Dalam soal esai itulah kemerdekaan ada, karena santri memang diberi kemerdekaan untuk menjawabnya," terang Kepala Madrasah Tsanawiyah Pondok Pesantren Al-Furqon, Singaparna, Tasikmalaya, Jawa Barat, Ali Ahmad Fauzi.

Sejatinya, konsep kemerdekaan dalam belajar sudah jauh dilakukan pesantren. Seperti dalam peramuan visi misi dengan langkah kongkret penerapan di proses penentuan materi, jadwal dan metode. "Pesantren mempunyai visi misi pendidikan tersendiri. Kalau tidak dibebaskan, dimerdekakan, tentu akan repot dalam pengimplementasiannya dalam penerapannya menentukan pelajaran (materi) yang dapat mendukung tercapainya visi misi," kata Ustadz Musbir, salah seorang pendidik di Pesantren AlFurqon.

Di pesantren, RPP bukan hal baru. RPP sudah sejak lama ada di pesantren. Di Gontor misalnya, yang konsepnya banyak diadopsi pesantren-pesantren modern lainnya, memiliki amaliatud tadris. Dalam salah satu prosedurnya harus membuat rencana pembelajaran, dan rencana pembelajaran ini disesuaikan dengan materi, metode yang diinginkan guru yang dianggap objektif untuk kondisi peserta didiknya.

Implementasi Merdeka Belajar di SMK Islam Insan Mulia

SMK Islam Insan Mulia mengusung visi sekolah kejuruan yang agamis, cerdas, mandiri dan mempunyai keterampilan yang mumpuni atau skillful serta berakhlak mulia. Visi ini diterapkan dalam berbagai program, seperti budaya sekolah, kegiatan keagamaan, ekstrakurikuler, dan lain sebagainya. Budaya sekolah yang islami terlihat dari penggunaan seragam, yang seluruh siswa dan guru diwajibkan memakai seragam yang islami; kebiasaan sebelum dan sesudah belajar; penanaman kebersihan sebagian dari iman; dan pembiasaan sapa, senyum, salam, sopan, dan santun.
Kegiatan keagamaan seperti kegiatan Shalat Dhuha, Dzuhur dan Ashar berjemaah, kegiatan muhadharah, pemberian materi hadits dan mahfudzat di luar materi pembelajaran PAI, tahfidz, pembinaan DKM, dan lain sebagainya. Kegiatan keislaman pun tercermin dari adanya ekstrakurikuler hadrah dan DKM siswa yang biasanya melaksanakan berbagai lomba keagaman serta kegiatan kajian baik di hari biasa ataupun di Bulan Ramadhan.

Berkenaan dengan implementasi kebijakan Merdeka Belajar Kepala SMK Islam Insan Mulia, Tetep Bimbing Gunadi S.Pd, M.Si menyatakan, guru-guru di SMK Islam Insan Mulia telah diberikan diklat dan pelatihan-pelatihan. Contohnya mengundang SEAMEO SEAMOLEC. Pelatihan-pelatihan lain sedang dipersiapkan. Menurutnya, agar pelaksanaan Merdeka Belajar berjalan baik, guru-guru juga harus dibekali materimateri baru dan meningkatkan kompetensinya.

"Sekolah akan mendatangkan narasumber atau praktis yang kompeten agar memantapkan potensi guru, baik melalui pelatihan maupun workshop. Untuk siswanya, pembelajarannya harus sesuai dengan kompetensinya. Itu akan kami terapkan nantinya," ucapnya.

Selain itu, SMK Islam Insan Mulia juga bakal melakukan studi banding ke sekolah lain yang sudah menerapkan kebijakan Merdeka Belajar. Tujuannya, agar SMK Islam Insan Mulia bisa memahami betul konsep tersebut dan cara mengimplementasikan dari sekolahsekolah yang sudah menerapkan Merdeka Belajar lebih dulu. Dengan begitu, saat diterapkan di SMK Islam Insan Mulia, kebijakan Merdeka Belajar dapat dilaksanakan dengan matang.

Berkenaan dengan merdeka memilih, SMK Islam Insan Mulia, sebagaimana sekolah kejuruan yang mempunyai ciri khas Islam, berusaha memberikan ilmuilmu fardhu a'in yang terdapat dalam materi PAI juga yang diterapkan dalam 
budaya sekolah, seperti pemberian jam untuk hafalan Al-Qur'an, hadits dan mahfudzot, pembiasaan Shalat Dhuha, Dhuhur dan Ashar berjemaah, kegiatan muhadharah dan motivasi keislaman setiap pagi. Kegiatan-kegiatan tersebut terkontrol melalui buku monitoring ibadah yang wajib dimiliki setiap peserta didik. Selain itu, untuk anggota DKM, ada pemberian kajian khusus keislaman dan tadarus bersama.

Yayasan Nurul Amal, yang menaungi SMK Islam Insan Mulia, juga membuka kelas asrama bagi peserta didik yang ingin menambah ilmu keagamaan. Kelas asrama ini menggunakan metode pesantren. Berbagai pendalaman agama diberikan kepada santri yang sekaligus peserta didik dari SMK Islam Insan Mulia. Dengan adanya kelas asrama ini, diharapkan ilmu-ilmu fardhu a'in dapat dikuasai dengan benar dan diamalkan dalam kehidupan sehari-hari, sehingga tujuan utama pendidikan nasional dan visi misi SMK Islam Insan Mulia yang mencetak generasi religius, mandiri, keterampilan dan berakhlak mulia, dapat tercapai.

Selain itu, SMKI Islam Insan Mulia memberikan perhatian besar pada pembelajaran PAI, dengan merumuskan manajemen pembelajaran PAI. Rumusan ini disampaikan Ketua Yayasan Nurul Amal, Dr. Suhardi, dalam Raker yang dilaksanakan pada tanggal 27 Juli 2021. Yang diperhatikan dari manajemen pembelajaran PAI antara lain adalah roadmap-nya, paradigmanya, SDM-nya, kurikulumnya, metode dan evaluasi, sarpras, regulasi, atmosfer kegiatan, sosialisasi, pelatihan, pengadaan buku pegangan, kecukupan alokasi waktu, pembinaan, dan networking. Dr Suhardi juga menekannya akan aspek penting dari penciptaan ruh keislaman dalam setiap atmosfer kegiatan di SMK Islam Insan Mulia. Dia menekan, atmosfer keagamaan ini harus diciptakan oleh semua civitas akademika SMK Islam Insan Mulia. Tidak hanya peserta didik, tetapi juga para guru dan seluruh staf. Contoh sederhananya adalah dengan selalu melaksanakan shalat berjamaah di masjid. Hal ini dilakukan agar tercipta GTK yang taat beribadah dan berakhlak mulia sehingga bisa menjadi contoh bagi peserta didik.

Hal lain yang tidak boleh diabaikan dalam Merdeka Belajar adalah proses evaluasi. Penulis mengatakan kepada beberapa guru tentang ini. Ada beberapa model penugasan yang diberikan kepada peserta didik untuk mengetahui hasil belajar, sebagian ada yang berupa soal pilihan ganda, ada yang memberikan soal esai, portofolio, atau berupa proyek dan produk.

Untuk evaluasi yang terjadwal seperti Penilaian Tengah Semester dan Akhir Semester, dilakukan dengan dua bentuk soal yang berbeda. Soal untuk PTS menggunakan esai, dan untuk Penilaian Akhir Semester dengan jenis soal pilihan ganda. Adapun untuk muatan produktif, terdapat ujian kompetensi.

Para guru diberi kebebasan untuk membuat soal sendiri, sesuai dengan materi-materi yang telah disampaikan. Namun, mayoritas masih sesuai dengan silabus. Untuk pelajaran umum, dalam penilaian sehari-hari tidak ada acuan baku soal atau penugasan seperti apa. Semua tergantung dari kreativitas guru. Pada saat pembelajaran berlangsung tatap muka, berbagai sistem penilain dan praktik kerap diterapkan oleh para guru. Namun, hal demikian berkurang efektivitasnya semenjak pembelajaran daring.

Kebijakan Merdeka Belajar selanjutnya yang sedang dipersiapkan adalah pelaksanaan asesmen nasional. Beberapa guru telah dipersiapkan menjadi panitia dan beberapa peserta didik yang terpilih untuk mengikuti asesmen nasional. Guru-guru Bahasa Indonesia dan Matematika, sudah mengetahui rencana asesmen ini. Mereka pun sudah mendapat juklis perihal pembuatan soal dan rancangan agenda proses asesmen ini. 


\section{KESIMPULAN}

Islam sangat menjunjung tinggi kebebasan. Termasuk dalam juga dalam proses pendidikan. Dalam proses pendidikan Islam, mulai dari zaman klasik sampai saat ini, konsep kebebasan itu terus diterapkan. Karena itu, kebijakan Merdeka Belajar yang diluncurkan Menteri Pendidikan dan Kebudayaan Nadiem Makarim selaras dengan konsep Pendidikan Islam.

Merdeka Belajar dapat disimpulkan sebagai belajar yang leluasa, bebas tidak terikat, yang menggerakan peserta didik agar mengembangkan seluruh potensi mereka untuk mencapai kapabilitas intelektual, moral, dan keterampilan lainya. Merdeka Belajar mendorong kemampuan berpikir siswa agar kreatif dalam mencari pengetahuan dari berbagai sumber. Siswa bisa bebas memilih belajar dari berbagai sumber dan bebas dari tekanan, pembelajaran berpusat pada siswa (student centered). Esensi penting Merdeka Belajar adalah merdeka dalam berpikir, baik secara individu maupun secara berkelompok, sehingga bisa melahirkan siswa-siswa yang kritis, kreatif, kolaboratif, inovatif dan partisipatif.

Dalam Islam, kita harus berikhtiar mencari pilihan terbaik. Istilah ikhtiar dapat kita tarik dari tafsir Q.S. Ar-Rad ayat 11. Dengan demikian, Merdeka Belajar dalam pendidikan Islam adalah sebuah ikhtiar untuk memilih yang khair atau yang terbaik. Jadi, kemerdekaan itu diberikan dengan pilihan-pilihan yang untuk membimbing peserta didik kepada kebaikan pula. Kemerdekaan diberikan kepada peserta didik dengan arahan dan bimbingan dari guru.

Merdeka Belajar dalam perspektif Islam dapat disimpulkan sebagai sebuah proses internal yang menggerakkan peserta didik agar menggunakan seluruh potensi fitrah, kognitif, afektif, dan psikomotorik secara merdeka, agar menjadi insan kamil yang memiliki berbagai kapabilitas intelektual, keterampilan, akhlakul karimah, membawa misi rahmatan lil a'lamin dengan tujuan ibadah kepada Allah SWT. Semua proses pembelajarannya dilakukan dengan menjunjung tinggi asas kemerdekaan sebagai makhluk Allah.

Implementasi Merdeka Belajar di SMK Islam Insan Mulia, baik konsep maupun kebijakan, telah diupayakan diterapkan secara maksimal. Namun, karena berbagai kendala, seperti masih barunya kebijakan Merdeka Belajar dan pandemi Covid-19 yang melanda selama hampir dua tahun, menjadi tantangan tersendiri. Oleh karena itu, perlu upaya yang lebih serius dan konsisten lagi serta dengan perencanaan yang matang dan berkelanjutan untuk memaksimalkan implementasi merdeka belajar ini.

\section{DAFTAR PUSTAKA}

Ali, Mohamad. 2017. Paradigma Pendidikan Berkemajuan. Yogyakarta: Suara Muhammadiyah. Ali Engineer, Asghar. 2009. Islam dan Teologi Pembebasan. Yogyakarta: Pustaka Pelajar.

Baharudin dan Esa Nur Wahyuni. 2007. Teori Belajar dan Pembelajaran. Yogyakarta: Ar-Ruz Media.

Diniyah, A. N., Dkk. 2018. "Analisis

Kemampuan Kemampuan

Penalaran dan Self Confidence Siswa SMA dalam Materi Peluang". Journal on Education. 1(1), 2018.

Hermino, Agustinus. 2020. Merdeka Belajar di Era Global dalam Perspektif Manajemen Pendidikan. Yogyakarta: Pustaka Pelajar.

Holosko, M. J., dkk. 2018. "Human Behavior in the Social Environment". Person-Centered Theory. John Wiley \& Sons Inc. Vol. 2, 2008.

Kumala Sari, Eva Dwi. 2017. "Isu-Isu Kritis dalam pendidikan: Lemahnya Kualitas Tes Ujian Akhir Sekolah Berstandar Nasional 
(UASBN) di Tingkat Sekolah

Dasar". Almarhal. Jurnal

Pendidikan Islam 1, No. 1 (2017).

Nata, Abuddin. 2009. Perspektif Islam tentang Strategi Pembelajaran. Jakarta: Kencana Prenada Media Group.

Nasution, Hasyim Syah. 1999. Filsafat Islam. Jakarta: Gaya Media Pratama.

Nizar, Samsul dan Zaenal Efendi Hasibuan. 2011. Hadis Tarbawi. Jakarta: Kalam Mulia.

Piong, Delpianus. 2020. "Penerapan Merdeka Belajar dalam Buku Teks Bahasa Inggris Talk Active Kelas XI". Jurnal UST Jogja. Yogyakarta: Vol. 1 No. 1, 2020.

Syafii Maarif, Ahmad. 1993. Peta Bumi Intelektualisme Islam di Indonesia. Bandung: Mizan.

Suharna, Ano. 2016. "Evaluasi Pendidikan dalam Perspektif Islam". QATHRUNA 3, No. 02 (Desember 11, 2016).

Yamin, Muhammad dkk. 2020. "Pembangunan Pendidikan Merdeka Belajar (Telaah Metode Pembelajaran)". Jurnal Ilmiah Mandala Education Vol. 6. No. 1. April 2020.

\section{Wawancara}

Ali Ahmad Fauzi, Kepala Madrasah Tsanawiyah Pondok Pesantren Muhammadiyah Al-Furqon, Singaparna, Tasikmalaya, Jawa Barat.

Muhammad Adriansyah, Praktisi Pendidikan/Direktur Pondok Pesantren at-Taqwa Depok, Jawa Barat.

Muhammad Iqbal, Pengajar di Pondok Pesantren Muhammadiyah AlFurqon, Tasikmalaya, Jawa Barat.

Mahmud, Guru Besar Pendidikan, Rektor Universitas Islam Negeri (UIN) Sunan Gunung Djati Bandung.

Tetep Bimbing Gunadi, Kepala SMK Islam Insan Mulia, Pagedangan, Tangerang. 